\title{
Non-pharmacological Approach in the Management of Functional Dyspepsia
}

\author{
Yen-Po Wang, ${ }^{1,2,3,4}$ Charles C Herndon, ${ }^{5}$ and Ching-Liang Lu ${ }^{1,2,3,4 *}$ \\ ${ }^{1}$ Institute of Brain Science, ${ }^{2}$ Faculty of Medicine, National Yang-Ming University School of Medicine, Taipei, Taiwan; ${ }^{3}$ Endoscopy Center \\ for Diagnosis and Treatment, ${ }^{4}$ Department of Medicine, Taipei Veterans General Hospital, Taipei, Taiwan; and ${ }^{5} \mathrm{G}$ Oppenheimer Center for \\ Neurobiology of Stress and Resilience (CNSR), David Geffen School of Medicine at UCLA, Los Angeles, CA, USA
}

Functional dyspepsia (FD) is a common functional gastrointestinal disease which bears a significant burden on society and individuals. Despite the high prevalence of FD, its pathophysiology remains poorly understood and the treatment options are limited and unsatisfactory. In the absence of effective pharmacological treatments for FD, non-pharmacological approaches, including: reassurance, lifestyle modification, psychotherapy, dietary interventions, medical food, acupuncture, and electrical stimulation and modulation are sought after by many physicians and FD patients. In this article, we review clinical studies which investigate nonpharmacological therapies for FD. We will also discuss potential mechanisms involved in the therapeutic effects of these nonpharmacological approaches. Though the evidences to support the routine use of the non-pharmacological management is still lacking, the non-invasive nature and potentially minimal side-effects of these therapies may be attractive in the FD management. In order to confirm the clinical effectiveness of these non-pharmacological approaches, more well-conducted, methodologically rigorous, and large-scaled clinical trials are required.

(J Neurogastroenterol Motil 2020;26:6-15)

Key Words

Complementary therapies; Dyspepsia; Electrical stimulation

\section{Introduction}

Functional dyspepsia (FD) refers to a group of symptoms arising from the epigastric region that do not originate from an organic disease. ${ }^{1} \mathrm{FD}$ is divided into 2 diagnostic categories of meal-related dyspeptic symptoms in the Rome IV criteria; they include: postprandial distress syndrome (PDS), characterized by postprandial fullness and early satiation, and epigastric pain syndrome (EPS), characterized by epigastric pain and burning. ${ }^{2}$ The prevalence of $\mathrm{FD}$ in Asia ranges from $8 \%$ to $23 \% .^{3}$ Though it is not a life- threatening disease, it significantly impairs patients' quality of life and bears a significant economic burden on society and individuals. ${ }^{4}$ Despite its high prevalence and disease burden, the pathophysiology of FD remains poorly understood. However, several mechanisms have been proposed, including: impaired gastric accommodation, ${ }^{5}$ delayed gastric emptying, ${ }^{6}$ visceral hypersensitivity, ${ }^{7}$ Helicobacter pylori infection, ${ }^{8}$ hypersensitivity to duodenal lipid or acid exposure, ${ }^{9,10}$ genetic factors, ${ }^{11}$ social and psychological factors, ${ }^{12}$ history of infectious colitis, ${ }^{13}$ and duodenal eosinophilia. ${ }^{14}$ Current guidelines for the treatment of FD suggest the use of proton pump inhibitors, the eradication of $H$. pylori, prokinetic drugs, and

Received: January 5, 2019 Revised: September 20, 2019 Accepted: October 9, 2019

() This is an Open Access article distributed under the terms of the Creative Commons Attribution Non-Commercial License (http://creativecommons. org/licenses/by-nc/4.0) which permits unrestricted non-commercial use, distribution, and reproduction in any medium, provided the original work is properly cited.

*Correspondence: Ching-Liang Lu, MD

Endoscopy Center for Diagnosis and Treatment, Taipei Veterans General Hospital, No. 201, Sec. 2, Shih-Pai Rd. Sec. 2, Taipei 111, Taiwan

Tel: +886-2-2875-2111 (ext. 3385), Fax: +886-2-2873-9318, E-mail: cllu@ym.edu.tw/cllu@vghtpe.gov.tw 
psychotropic agents. ${ }^{15}$ Nonetheless, the efficacy of these pharmacological therapies remains unsatisfactory and a considerable number of FD patients are refractory to conventional pharmacological treatments. Furthermore, low compliance of the traditional therapy can be observed in some FD patients as they would opt out from these pharmacological options because of the concerns on the side effects. ${ }^{16,17}$ In the absence of an approved drug to treat $\mathrm{FD},{ }^{18}$ many patients seek person-centered, non-pharmacological approaches. ${ }^{19}$ These therapies include reassurance, lifestyle modification, psychotherapy, dietary interventions, medical food, acupuncture, or electrical stimulation and modulation. This review will discuss the efficacy, potential mechanisms, and opportunities for the improvement of non-pharmacological therapies for FD.

We performed a systematic approach in the collection and review of relevant literature. PubMed was searched from 1994 through to December 2018 with a combination of the following basic and MeSH (medical subject headings) terms: "functional dyspepsia" or "functional gastrointestinal disorder" as the population; "medical food," "acupuncture," "psychotherapy," "electrical stimulation" or "non-pharmacological" as the intervention; "placebo" or "control" as the comparison; and "placebo controlled" or "randomized" as the study design. Reference lists of included studies were then manually searched for relevant studies.

\section{Placebo Effect and Its Clinical Application in Functional Dyspepsia Patients}

A number of clinical trials have shown that patients with functional bowel disorders (eg, FD, irritable bowel syndrome [IBS], etc) benefit from a greater placebo response when compared to patients with organic gastrointestinal diseases. ${ }^{20}$ One meta-analysis including $45 \mathrm{FD}$ trials showed a placebo response rate of $31 \%$ to $45 \%{ }^{21}$ A 2006 Cochrane review found an average $56 \%$ placebo response among FD patients. ${ }^{22}$ The underlying mechanisms behind the high placebo response rate among FD patients are still unclear, however, no studies have found a significant difference in the personality traits between placebo responders and non-responders. To date, the only factors predictive of a lower placebo response rate are a body mass index of lesser than 25 and a consistent predominant symptom pattern. ${ }^{20}$ Talley et $\mathrm{al}^{20}$ suggested that the placebo response to treatment can be maximized by a firm diagnosis that must be followed by explanation and reassurance. In daily practice, clinicians may take advantage of the placebo effect by reassuring the FD patient by explaining the pathophysiology of FD and the unlikelihood of cancer in order to relieve patients' anxiety and lead to symptomatic improvement.

\section{Lifestyle Modification}

Lifestyle factors are linked with the development of dyspeptic symptoms. For example, life stress, anxiety, and the use of inadequate coping strategies are predictors of $\mathrm{FD}^{23}$ Furthermore, anxiety was associated with PDS, but not with the EPS in a Swedish population study. ${ }^{24}$ A Taiwanese FD study showed that PDS was independently associated with dimensions of somatization, depression, and phobia. ${ }^{25}$ In addition, we and Miwa et $\mathrm{al}^{26}$ both found that FD patients have a higher prevalence of sleep difficulties. ${ }^{4} \mathrm{~A}$ large United States-based community study demonstrated that difficulty falling asleep is an independent risk factor for dyspepsia. ${ }^{27}$ Though the studies evaluating the beneficial effect of adjustments in lifestyle are lacking, measurements to improve lifestyle may relieve dyspeptic symptoms. FD patients with refractory and persistent symptoms after conventional treatment may attempt lifestyle modification.

\section{Psychotherapy}

Numerous studies have evaluated psychological therapy in the treatment of IBS, ${ }^{28}$ however, the body of evidence in support of psychological therapies for FD is rather limited. Nonetheless, patients who suffer from psychiatric comorbidities or who are otherwise nonresponsive to pharmacological interventions may be suitable candidates for psychological therapy. Various methods of psychotherapy in the treatment of FD have been evaluated, including hypnotherapy, ${ }^{29}$ cognitive behavioral therapy, ${ }^{30-34}$ and psychoanalytic psychotherapy, ${ }^{35,36}$ as summarized in Table 1. The American College of Gastroenterologists and the Canadian Association of Gastroenterologists recently reviewed psychotherapy among other interventions in the treatment of FD. Each of the 12 trials reviewed indicated a significant benefit from psychological therapies compared to control (relative risk [RR], 0.53; 95\% confidence interval [CI], 0.44-0.65) with a number needed to treat of 3 . Despite these positive results, the reviewers stated that the evidential basis for psychotherapy in the treatment of FD is weak. This is because the research to date has been far too heterogeneous - both in terms of the study populations and type of psychotherapeutic intervention - for any definitive support favoring the use of psychotherapy in the treatment of $\mathrm{FD}^{37}$ It can be difficult to judge the therapeutic effect objectively due to the heterogeneity in psychological treatment methods. The studied patients also ranged in their duration of illness and varied in the symptoms of FD that they had reported. The included studies also lacked methodological rigor; the study interventions were neither blinded nor were various interventions directly compared with each other. In addition, unlike the current standards for pharmaceutical 
Table 1. Summary of Studies on Psychotherapy for the Treatment of Functional Dyspepsia

\begin{tabular}{|c|c|c|c|c|}
\hline References & Trial design & Patient & Treatment groups & Main finding \\
\hline Calvert et $\mathrm{al}^{29}$ & $\begin{array}{l}\text { Randomized } \\
\text { controlled trial }\end{array}$ & $\begin{array}{l}\text { FD patients } \\
(\mathrm{n}=93)\end{array}$ & $\begin{array}{l}16 \text { weeks of hypnotherapy }(\mathrm{n}=27) \text {, sup- } \\
\text { portive therapy plus placebo medication } \\
(\mathrm{n}=32) \text {, or ranitidine } 150 \mathrm{mg} \text { bid }(\mathrm{n}= \\
34)\end{array}$ & $\begin{array}{l}\text { Hypnotherapy is more effective than med- } \\
\text { ical treatment or supportive therapy plus } \\
\text { placebo medication in both the short- and } \\
\text { long-term management of FD. }\end{array}$ \\
\hline $\begin{array}{l}\text { Dehghanizade } \\
\text { et } \mathrm{al}^{30}\end{array}$ & $\begin{array}{l}\text { Pre-test, post-test and } \\
\text { follow-up with a con- } \\
\text { trol group }\end{array}$ & $\begin{array}{l}\text { FD patients } \\
(\mathrm{n}=30)\end{array}$ & $\begin{array}{l}10 \text { sessions of cognitive behavioral stress } \\
\text { management }(n=15) \text { or no intervention } \\
(n=15)\end{array}$ & $\begin{array}{l}\text { Cognitive-behavioral stress management } \\
\text { strategies are effective in reducing symp- } \\
\text { toms in patients with FD compared with } \\
\text { control. }\end{array}$ \\
\hline Cheng et $\mathrm{al}^{31}$ & $\begin{array}{l}\text { Randomized con- } \\
\text { trolled trial }\end{array}$ & $\begin{array}{l}\text { FD patients } \\
(\mathrm{n}=75)\end{array}$ & $\begin{array}{l}12 \text { weeks with } 6 \text { sessions of flexible cop- } \\
\text { ing psychotherapy }(n=33) \text { or support- } \\
\text { ive psychotherapy }(n=31)\end{array}$ & $\begin{array}{l}\text { Both flexible coping psychotherapy and } \\
\text { supportive psychotherapy effectively re- } \\
\text { duced FD symptoms. }\end{array}$ \\
\hline Hamilton et al ${ }^{36}$ & $\begin{array}{l}\text { Randomized con- } \\
\text { trolled trial }\end{array}$ & $\begin{array}{l}\text { FD patients } \\
(\mathrm{n}=73)\end{array}$ & $\begin{array}{l}12 \text { weeks of PI }(n=37) \text { or supportive } \\
\text { therapy }(n=36)\end{array}$ & $\begin{array}{l}\text { One year after treatment, the symptomatic } \\
\text { scores were similar. After excluding pa- } \\
\text { tients with severe heartburn, PI therapy } \\
\text { was superior to the control condition at } 1 \\
\text { year. }\end{array}$ \\
\hline Haug et $\mathrm{al}^{33}$ & $\begin{array}{l}\text { Randomized con- } \\
\text { trolled trial }\end{array}$ & $\begin{array}{l}\text { FD patients } \\
(\mathrm{n}=100)\end{array}$ & $\begin{array}{l}4 \text { months of cognitive psychotherapy (n } \\
=50) \text { or control treatment }(\mathrm{n}=50)\end{array}$ & $\begin{array}{l}\text { Psychotherapy significantly reduce epigas- } \\
\text { tric pain, nausea, heartburn, diarrhea, and } \\
\text { constipation. }\end{array}$ \\
\hline Orive et $\mathrm{al}^{32}$ & $\begin{array}{l}\text { Randomized con- } \\
\text { trolled trial }\end{array}$ & $\begin{array}{l}\text { FD patients } \\
(\mathrm{n}=158)\end{array}$ & $\begin{array}{l}10 \text { weeks of medical therapy plus psy- } \\
\text { chotherapy }(n=76) \text { or medical therapy } \\
\text { alone }(n=82)\end{array}$ & $\begin{array}{l}\text { Adding psychotherapy to medical therapy } \\
\text { improves short-term outcomes in FD } \\
\text { patients. }\end{array}$ \\
\hline Haag et $\mathrm{al}^{34}$ & $\begin{array}{l}\text { Randomized con- } \\
\text { trolled trial }\end{array}$ & $\begin{array}{l}\text { FD patients } \\
(\mathrm{n}=100)\end{array}$ & $\begin{array}{l}4 \text { months of standardized symptom- } \\
\text { oriented therapy }(\mathrm{n}=24) \text { or intensive } \\
\text { medical therapy with either progressive- } \\
\text { muscle relaxation }(\mathrm{n}=20) \text { or }(\mathrm{n}=28) \text {, } \\
\text { or intensive medical therapy only }(\mathrm{n}= \\
28)\end{array}$ & $\begin{array}{l}\text { Intensified medical therapy involving } \\
\text { sensory-motor function tests and psycho- } \\
\text { logical intervention yields superior long- } \\
\text { term outcomes. }\end{array}$ \\
\hline Faramarzi et $\mathrm{al}^{35}$ & $\begin{array}{l}\text { Randomized con- } \\
\text { trolled trial }\end{array}$ & $\begin{array}{l}\text { FD patients } \\
(\mathrm{n}=49)\end{array}$ & $\begin{array}{l}18 \text { weeks of core conflict relationship } \\
\text { themed psychoanalytic psychotherapy (n } \\
=24) \text { or standard medication treatment } \\
(\mathrm{n}=25)\end{array}$ & $\begin{array}{l}\text { Core conflict relationship themed psycho- } \\
\text { therapy can serve as an effective interven- } \\
\text { tion for gastrointestinal and psychiatric } \\
\text { symptoms in FD patients. }\end{array}$ \\
\hline
\end{tabular}

FD, functional dyspepsia; PI, psychodynamic-interpersonal.

drug trials, the lack of a placebo arm in the clinical trials involving psychotherapy also weakens the evidence for such therapy. Furthermore, the use of psychotherapy in FD patients is lessened by a lack of familiarity among gastroenterologists with such interventions, as well as patients who do not recognize or are unwilling to accept the influence of psychological symptoms on the severity of gastrointestinal symptoms. Future studies should address these limitations in order to convince patients and healthcare providers to introduce psychotherapy for the treatment of FD.

\section{Dietary Management and Medical Food}

Starting from the Rome III consensus, FD, and in particular PDS, has been considered a disorder related to food ingestion. ${ }^{38}$
Avoiding foods which trigger indigestion may be of benefit. Several studies and systemic reviews have indicated that wheat-containing foods, fatty or spicy foods, and carbonated drinks can trigger dyspeptic symptoms, ${ }^{39}$ as summarized in Table 2. However, it is not yet understood exactly how these foods trigger FD symptoms.

Another dietary intervention for the treatment of FD is medical food; defined by the United States Food and Drug Administration as foods which are formulated to be consumed or administered enterally under the supervision of a physician which is intended for the specific dietary management of a disease or condition. ${ }^{40,41}$ Medical foods, unlike food supplements, require safety reviews by panels of toxicologists and must be generally recognized as safe for consumption, although phase 1,2 , and 3 trials are not required. ${ }^{42}$ 
Table 2. Food and Food Components Reported in Association With Dyspeptic Symtpoms ${ }^{39}$

\begin{tabular}{ll}
\hline \multicolumn{1}{c}{ Category } & \multicolumn{1}{c}{ Ingredients } \\
\hline $\begin{array}{l}\text { Grains, nuts, } \\
\text { and seeds }\end{array}$ & Grains, wheat containing food, nuts \\
$\begin{array}{l}\text { Meats } \\
\text { Vegetables }\end{array}$ & $\begin{array}{l}\text { Sausage, bologna, bacon, fish } \\
\text { Pickles/vinegar, red pepper, bell pepper, cucum- } \\
\text { ber onions, beans, horseradish }\end{array}$ \\
Dairy & $\begin{array}{l}\text { Milk, cheese, some mayonnaise, cream } \\
\text { Sweets and fats }\end{array}$ \\
Fruits & Whocolate, high fat yogurt, sweets, cake \\
Drinks & Carbonated drinks, tea, coffee, wine, beer \\
Others & Fatty food, fried food, fumed food, baked food, \\
& pizza, pasta, spices \\
\hline
\end{tabular}

Medical foods can affect several pathophysiological mechanisms in FGIDs, such as functioning as an anti-inflammatory, causing smooth muscle relaxation, analgesia, mitigation of gut barrier dysfunction, and stimulation or inhibition of gastrointestinal receptors. ${ }^{41}$ Several medical foods are available in Europe and United States for the treatment of FD. In Western countries, caraway oil (CO) has often been combined with peppermint oil (PO) in order to treat abdominal discomfort and pain. Two randomized controlled trials have demonstrated that this $\mathrm{PO}+\mathrm{CO}$ combination improves FD patients' global symptom impressions in a manner comparable with cisapride ${ }^{43}$ and superior to placebo. ${ }^{44} \mathrm{~A}$ separate randomized controlled trial (RCT) compared the efficacy of $\mathrm{CO}+\mathrm{L}$-menthol (FDgard) or a placebo as adjuvants to conventional medications in the treatment of FD. After 4 weeks of treatment, the $\mathrm{CO}+\mathrm{L}$ menthol group showed improved clinical global impressions to a greater extent than placebo ( $61.2 \%$ vs $48.9 \%$, respectively), however, the difference was not statistically significant. $\mathrm{CO}$ is thought to produce its therapeutic effect through a prokinetic effect whereas PO produces its therapeutic effect via kappa-opioid-receptor dependent anti-nociception, anti-inflammatory properties, and TRPM8-receptor dependent smooth muscle relaxation. ${ }^{41}$

Another medical food of interest is STW 5-an herb composed of garden angelic root, milk thistle fruits, greater celandine, bitter candy tuft, caraway fruits, liquorice root, chamomile flowers, balm leaves, and peppermint leaves. STW 5 has been used to treat a variety of functional digestive symptoms. ${ }^{45}$ In a meta-analysis of 3 RCTs evaluating STW 5 in the treatment of FD, Melzer et $\mathrm{al}^{46}$ found treatment with STW $5(\mathrm{n}=138)$ to be more effective than placebo $(\mathrm{n}=135)$ with regard to the severity of the most bothersome gastrointestinal symptom $(P=0.001 ; \mathrm{OR}, 0.22 ; 95 \% \mathrm{CI}$, $0.11-0.47)$. An RCT by von Arnim et $\mathrm{al}^{47}$ found a similarly favor- able result: statistically significant improvement in Gastrointestinal Symptom Score in the STW 5 arm $(\mathrm{n}=158)$ as compared to the placebo arm $(\mathrm{n}=157)(6.9 \pm 4.8$ vs $5.9 \pm 4.3$ at 56 days, $P<$ $0.05)$. It has been suggested that the therapeutic mechanism of STW 5 includes a decrease in muscle tone within the gastric fundus that enhances antral contractility. ${ }^{45}$ However, Braden et $\mathrm{al}^{48}$ found that the clinical effects of STW 5 in FD patients with FD and gastroparesis were not directly mediated by an acceleration of gastric emptying. No serious adverse events have been reported in the RCTs evaluating STW 5 for FD. ${ }^{46-48}$ Though STW 5 is thought to be a safe remedy and available without doctor's prescription in many countries including the United States, STW 5 is linked with drug-induced liver injury in recent 2 case reports, which might be the results from an idiosyncratic reaction. ${ }^{49,50}$

Another non-pharmacological avenue for the treatment of FD is probiotics. Probiotics are living microorganisms that (when consumed) have the potential to confer a beneficial health effect; they can be marketed as a medical food. ${ }^{51}$ Probiotics containing Lactobacillus gasseri have demonstrated a beneficial effect on FD symptoms. A placebo-controlled study by Ohtsu et al $\mathrm{a}^{52}$ recruited $106 \mathrm{FD}$ patients and found the elimination rate for PDS-like symptoms was $17.8 \%$ and $37.5 \%$ in the placebo and $L$. gasseri groups, respectively $(P=0.040)$. The elimination rate for EPS-like symptoms was not statistically significant. Nakae and colleagues ${ }^{53}$ evaluated the effects of an L. gasseri-containing yogurt on the gastrointestinal symptoms and composition of enteric bacteria in FD patients vs healthy controls. They found that the abundance of the bacterial genus Prevotella was reduced in the gastric fluid of FD patients compared to healthy controls. Interestingly, there was a significant inverse correlation between Prevotella abundance and the severity of PDS-like symptoms in patients with FD that was nearly reversed by probiotic treatment. Their findings suggest that the gastric fluid's abundance of Prevotella may be used as a biomarker of the efficacy of $L$. gasseri-containing probiotics for the treatment of $\mathrm{FD}{ }^{53}$

Medical foods may appeal to those who have failed conventional therapies or who are seeking dietary management for their FD symptoms. Table 3 displays trials investigating medical food to treat FD. What is considered medical food varies between regions. Till now, there has not been enough evidence to warrant the clinical use of medical foods. Future large, well-controlled studies are needed to assess both the safety and efficacy of medical foods in the treatment of $\mathrm{FD}$ patients with different races and ethnicities. 
Table 3. Summary of Studies on Medical Foods for the Treatment of Functional Dyspepsia

\begin{tabular}{|c|c|c|c|c|}
\hline References & Trial design & Patient & Treatment groups & Main finding \\
\hline May et $\mathrm{al}^{44}$ & $\begin{array}{l}\text { Randomized } \\
\text { controlled trial }\end{array}$ & $\begin{array}{l}\text { FD patients } \\
(\mathrm{n}=96)\end{array}$ & $\begin{array}{l}4 \text { weeks of } 90 \mathrm{mg} \mathrm{PO}+50 \mathrm{mg} \\
\mathrm{CO}(\mathrm{n}=48) \text { or placebo }(\mathrm{n}=48)\end{array}$ & $\begin{array}{l}\mathrm{PO}+\mathrm{CO} \text { were superior to placebo in improving } \\
\text { global symptom impression and pain intensity. }\end{array}$ \\
\hline $\begin{array}{l}\text { Madisch } \\
\text { et } \mathrm{al}^{43}\end{array}$ & $\begin{array}{l}\text { Randomized } \\
\text { controlled trial }\end{array}$ & $\begin{array}{l}\text { FD patients } \\
(\mathrm{n}=118)\end{array}$ & $\begin{array}{l}90 \mathrm{mg} \mathrm{PO}+50 \mathrm{mg} \text { CO per day } \\
(\mathrm{n}=60) \text { or cisapride }(3 \times 10 \\
\mathrm{mg} / \text { day })(\mathrm{n}=58)\end{array}$ & $\begin{array}{l}\mathrm{PO}+\mathrm{CO} \text { were comparable with cisapride and pro- } \\
\text { vides an effective means for treatment of FD. }\end{array}$ \\
\hline Chey et $\mathrm{al}^{54}$ & $\begin{array}{l}\text { Randomized } \\
\text { controlled trial }\end{array}$ & $\begin{array}{l}\text { FD patients with } \\
\operatorname{PDS}(n=34) \text { or } \\
\operatorname{EPS}(n=39)\end{array}$ & $\begin{array}{l}4 \text { weeks of } 50 \mathrm{mg} \mathrm{CO}+41.5 \mathrm{mg} \\
\mathrm{L} \text {-menthol twice } / \text { day }(\mathrm{n}=37) \text { or } \\
\text { placebo }(\mathrm{n}=36)\end{array}$ & $\begin{array}{l}\mathrm{PO}+\mathrm{CO} \text { group showed non-significantly im- } \\
\text { proved clinical global impressions to a greater ex- } \\
\text { tent than placebo }(61.2 \% \text { vs } 48.9 \%, P>0.05) \text {. }\end{array}$ \\
\hline $\begin{array}{l}\text { von Arnim } \\
\text { et } \mathrm{al}^{47}\end{array}$ & $\begin{array}{l}\text { Randomized } \\
\text { controlled trial }\end{array}$ & $\begin{array}{l}\text { FD patients } \\
(\mathrm{n}=315)\end{array}$ & $\begin{array}{l}\text { STW } 5(\mathrm{n}=158) \text { or placebo } \\
(\mathrm{n}=157)\end{array}$ & $\begin{array}{l}\text { STW } 5 \text { significantly improved gastrointestinal } \\
\text { symptom scores compared to placebo. }\end{array}$ \\
\hline Melzer et $\mathrm{al}^{46}$ & $\begin{array}{l}\text { Meta-analysis of } \\
3 \text { randomized } \\
\text { controlled trials }\end{array}$ & $\begin{array}{l}\text { FD patients } \\
(\mathrm{n}=273)\end{array}$ & $\begin{array}{l}4 \text { weeks of } 1 \mathrm{~mL} \text { STW } 5 \text { three } \\
\text { times/day }(\mathrm{n}=138) \text { or placebo } \\
(\mathrm{n}=135)\end{array}$ & $\begin{array}{l}\text { STW } 5 \text { was superior to placebo in improving epigas- } \\
\text { tric pain, acid regurgitation, retrosternal troubles, } \\
\text { nausea, vomiting, and abdominal cramps as well as } \\
\text { patients' most bothersome symptom. }\end{array}$ \\
\hline Rösch et $\mathrm{al}^{55}$ & $\begin{array}{l}\text { Randomized } \\
\text { controlled trial }\end{array}$ & $\begin{array}{l}\text { Dysmotility type } \\
\text { FD patients } \\
(\mathrm{n}=186)\end{array}$ & $\begin{array}{l}\text { STW } 5(n=61), \text { STW 5-II } \\
(\mathrm{n}=62) \text {, or cisapride }(\mathrm{n}=63)\end{array}$ & $\begin{array}{l}\text { STW } 5 \text { and the research preparation STW } 5 \text {-II } \\
\text { showed equivalent efficacy to cisapride for the treat- } \\
\text { ment of FD patients. }\end{array}$ \\
\hline Braden et $\mathrm{al}^{48}$ & $\begin{array}{l}\text { Randomized } \\
\text { controlled trial }\end{array}$ & $\begin{array}{l}\text { FD patients } \\
(\mathrm{n}=103)\end{array}$ & $\begin{array}{l}4 \text { weeks of } 1 \mathrm{~mL} \text { STW } 5 \text { three } \\
\text { times/day }(\mathrm{n}=41) \text { or placebo } \\
(\mathrm{n}=41)\end{array}$ & $\begin{array}{l}\text { Gastric half-emptying time was comparable between } \\
\text { groups. STW } 5 \text { improved gastrointestinal symptom } \\
\text { score and had a greater treatment response rate } \\
\text { compared to placebo. }\end{array}$ \\
\hline Xiao et $\mathrm{al}^{56}$ & $\begin{array}{l}\text { Randomized } \\
\text { controlled trial }\end{array}$ & $\begin{array}{l}\text { Children with FD } \\
(\mathrm{n}=120)\end{array}$ & $\begin{array}{l}\text { Sea buckhorn }(n=40) \text {, sea buck- } \\
\text { horn plus domperidone }(n=40) \text {, } \\
\text { or domperidone only }(n=40)\end{array}$ & $\begin{array}{l}\text { Sea buckthorn improved gastric emptying, gastric } \\
\text { mobility, gastrointestinal digestive function com- } \\
\text { pared to those receiving domperidone alone. }\end{array}$ \\
\hline Ohtsu et $\mathrm{al}^{52}$ & $\begin{array}{l}\text { Randomized } \\
\text { controlled trial }\end{array}$ & $\begin{array}{l}\text { H. pylori (-) FD } \\
\text { patients } \\
(\mathrm{n}=106)\end{array}$ & $\begin{array}{l}12 \text { weeks of } 10^{9} \mathrm{CFU} / \text { day } L \text {. } \\
\text { gasseri-containing yogurt } \\
(\mathrm{n}=54) \text { or placebo }(\mathrm{n}=52)\end{array}$ & $\begin{array}{l}\text { The elimination rate for postprandial-distress symp- } \\
\text { toms was } 17.8 \% \text { and } 37.5 \% \text { in the placebo and } L \text {. } \\
\text { gasseri groups, respectively }(P=0.040) \text {. The } \\
\text { elimination rate for epigastric pain symptoms was } \\
\text { not statistically significant. }\end{array}$ \\
\hline Nakae et $\mathrm{al}^{53}$ & Open-label trial & $\begin{array}{l}\text { FD patients } \\
(\mathrm{n}=44) \text { or } \\
\text { healthy controls } \\
(\mathrm{n}=44)\end{array}$ & $\begin{array}{l}12 \text { weeks of } 10^{9} \mathrm{CFU} / \text { day L. gas- } \\
\text { seri-containing yogurt }(\mathrm{n}=88)\end{array}$ & $\begin{array}{l}\text { L. gasseri-containing yogurt improved FD symp- } \\
\text { toms as well as helped normalize enteric microbial } \\
\text { composition to compositions found in healthy con- } \\
\text { trols. Prevotella abundance was inversely correlated } \\
\text { with FD symptom severity. }\end{array}$ \\
\hline
\end{tabular}

FD, functional dyspepsia; PO, peppermint oil; CO, caraway oil; PDS, postprandial distress syndrome; EPS, epigastric pain syndrome; STW 5, garden angelic root, milk thistle fruits, greater celandine, bitter candy tuft, caraway fruits, liquorice root, chamomile flowers, balm leaves, and peppermint leaves; STW 5-II, bitter candy tuft, caraway fruits, liquorice root, chamomile flowers, balm leaves, and peppermint leaves; H. pylori, Helicobacter pylori; CFU, colony-forming units; L. gasseri, Lactobacillus gasseri.

\section{Acupuncture}

Acupuncture has been increasingly used as a non-pharmacological treatment of FD. Traditionally, acupuncture involves the stimulation of acupuncture points by penetration of the skin with solid metallic needles, followed by manual manipulation of the needle (ie, twisting, lifting, and thrusting). Acupuncture points can also be stimulated through electro-acupuncture, passing electrical currents through an inserted needle to stimulate a specific acupuncture point at a certain frequency and intensity. Unlike traditional acupuncture, electro-acupuncture provides a more objective, quantifiable method of acupuncture. ${ }^{57}$ Two meta-analyses have evaluated the efficacy and safety of acupuncture to treat FD patients. The analysis by Kim et $\mathrm{al}^{58}$ included $20 \mathrm{RCT}$ and a total of 1423 FD patients who received either acupuncture or another therapy (meta-analysis 1). The second analysis by Zhou and colleagues ${ }^{59}$ included 24 RCTs and a total of 3097 FD patients receiving either acupuncture or electroacupuncture therapy (meta-analysis 2). Both meta-analyses showed that acupuncture was more beneficial than 
sham (meta-analysis 1: RR, 2.66; 95\% CI, 1.85-3.22; meta-analysis 2: RR, 2.03; 95\% CI, 1.55-2.67) and with usual pharmacological medications (meta-analysis 1: RR, 1.18; 95\% CI, 1.09-1.27; metaanalysis 2: RR, 1.10; 95\% CI, 1.04-1.17). Both meta-analyses also demonstrated that acupuncture enhanced the therapeutic benefit of FD medications (meta-analysis 1: RR, 1.23; 95\% CI, 1.02-1.48; meta-analysis 2: RR, 1.24; 95\% CI, 1.16-1.33).

In order to better understand acupuncture's therapeutic mechanism, a recent study used functional brain imaging (positron emission scan) in FD patients to evaluate the response in brain activity to acupuncture treatment. Acupuncture treatment resulted in a decrease in FD symptom scores that correlated with an extensive deactivation of cerebral activity in the brainstem, anterior cingulate cortex, insula, thalamus, and hypothalamus. ${ }^{60}$ This finding suggests that acupuncture's therapeutic mechanism may involve modulation of the homeostatic afferent processing network.

While these studies show a beneficial effect on FD symptoms, there are several limitations. The two meta-analyses included studies mostly from Eastern countries, namely China. Secondly, there has not yet been a multicenter, large-scale RCT for acupuncture in the treatment of FD. Furthermore, in many studies included in the meta-analysis, the definition of FD varied widely. FD can be based on Rome I, II, or III criteria or just vague dyspeptic symptoms not defined by Rome, and the outcomes after acupuncture were evalu- ated either dichotomously or continuously. Thus, the final results may be biased. Thirdly, most studies have had a short (if any) duration of follow-up. Fourthly, studies to date have lacked a standardized method of symptom evaluation, such as the Nepean Dyspepsia Index. Finally, most studies used fixed acupuncture points, such as Stomach-36 (ST36) and Pericardium-6 (PC6) as opposed to the traditional approach of selecting acupuncture points based off of each individual's symptoms. Given these limitations, a recent Cochrane review stated that "It remains unknown whether manual acupuncture or electro-acupuncture is more effective or safer than other treatments" in FD patients. ${ }^{61}$ Future large-scaled, multinational, and methodologically rigorous clinical trials are needed to confirm the effectiveness of acupuncture in treating FD patients.

\section{Electrical Stimulation/Modulation}

Transcutaneous electrical stimulation of acupuncture points, also known as transcutaneous electrical acu-stimulation (TEA), is a recent variant of electro-acupuncture that has been used in the treatment of FD (Table 4). ${ }^{62}$ TEA uses electrodes placed on the skin's surface for electrical stimulation. Having electrodes on the skin's surface reduces the depth of penetration of the electrical current. Compared to electro-acupuncture and conventional acupuncture, TEA is less invasive, can be self-administered by the patient, and can be conducted more frequently. Two trials have evaluated the ef-

Table 4. Summary of Studies on Electrical Acupuncture and Electrical Modulation for the Treatment of Functional Dyspepsia

\begin{tabular}{|c|c|c|c|c|}
\hline References & Trial design & Patient & Treatment groups & Main finding \\
\hline Köklü et al ${ }^{65}$ & $\begin{array}{l}\text { Randomized } \\
\text { controlled trial }\end{array}$ & FD patients $(n=44)$ & $\begin{array}{l}12 \times 15 \text { min sessions over } 4 \mathrm{wk} \\
\text { of vacuum interferential current } \\
\text { therapy at Bladder } 18-21(\mathrm{n}= \\
23) \text { or sham }(\mathrm{n}=21)\end{array}$ & $\begin{array}{l}\text { During treatment, therapy was superior to placebo } \\
\text { with respect to epigastric discomfort, pyrosis, bloat- } \\
\text { ing, early satiation, and postprandial fullness. One } \\
\text { month after treatment, therapy was superior to pla- } \\
\text { cebo with regard to early satiation and heartburn. }\end{array}$ \\
\hline Ji et al ${ }^{63}$ & $\begin{array}{l}\text { Randomized } \\
\text { crossover trial }\end{array}$ & FD patients $(\mathrm{n}=28)$ & $\begin{array}{l}2 \text { wk of TEA self-administered } \\
3 \times 2 \mathrm{hr} / \text { day at ST } 36 \text { and PC } 6 \\
\text { followed by } 2 \text { wk of sham-TEA, } \\
\text { or vice versa } \\
(\mathrm{n}=28)\end{array}$ & $\begin{array}{l}\text { TEA but no sham-TEA significantly improved gas- } \\
\text { tric emptying accommodation as well as dyspeptic } \\
\text { symptoms. }\end{array}$ \\
\hline Xu et $\mathrm{al}^{64}$ & $\begin{array}{l}\text { Placebo-con- } \\
\text { trolled pilot } \\
\text { trial }\end{array}$ & $\begin{array}{l}\text { FD patients }(\mathrm{n}=8) \\
\text { and healthy controls } \\
(\mathrm{n}=8)\end{array}$ & $\begin{array}{l}\text { TEA at ST } 36 \text { and PC6 }(\mathrm{n}=8) \\
\text { or sham }(\mathrm{n}=8) \text { with } 1 \times 30 \\
\text { min session before and } 1 \times 30 \\
\text { min session after a liquid meal }\end{array}$ & $\begin{array}{l}\text { In FD patients, TEA improved gastric accommo- } \\
\text { dation abnormalities in postprandial gastric slow } \\
\text { waves, and increased vagal activity. }\end{array}$ \\
\hline Kovacik $\mathrm{K}^{66}$ & $\begin{array}{l}\text { Placebo con- } \\
\text { trolled trial }\end{array}$ & $\begin{array}{l}\text { Adolescents with } \\
\text { chronic functional } \\
\text { abdominal pain } \\
(\mathrm{n}=104)\end{array}$ & $\begin{array}{l}\text { PENFS }(\mathrm{n}=57) \text { or placebo } \\
(\mathrm{n}=57)\end{array}$ & $\begin{array}{l}\text { Patients in the PENFS group had lower "worst pain } \\
\text { score" than with sham group after } 3 \text { wk of treat- } \\
\text { ment. Such analgesic effects were sustained for } 9.2 \\
\text { wk. }\end{array}$ \\
\hline
\end{tabular}

FD, functional dyspepsia; TEA, transcutaneous electrical acu-stimulation; ST36, Stomach-36; PC6, Pericardium-6; PENFS, percutaneous electric nerve field stimulation. 
ficacy of TEA in the treatment of FD. In a crossover study of FD patients, Ji et al ${ }^{63}$ conducted TEA at acupuncture points ST36 and PC6 for 2 weeks followed by 2 weeks of transcutaneous electrical stimulation at sham acupuncture points, or vice versa (Figure). They found TEA was superior to sham in decreasing dyspeptic

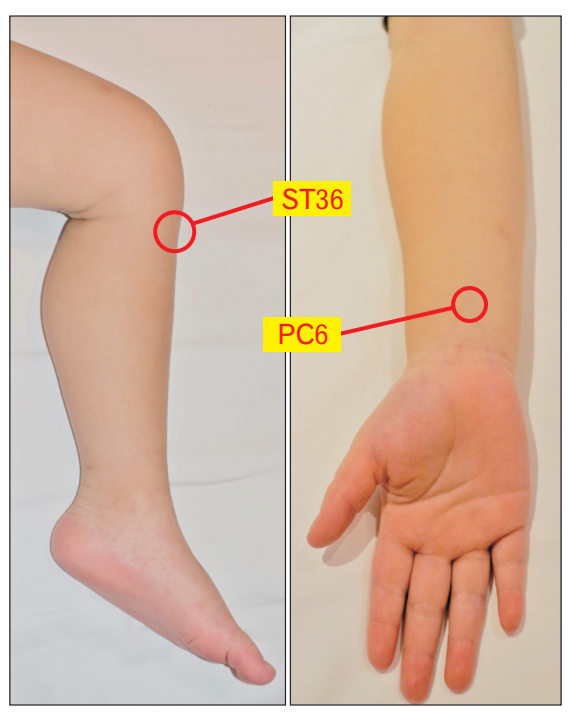

Figure. The location of Stomach-36 (ST36; Zusanli) and Pericardium-6 (PC6; Neiguan) acupoints. ST 36 is located in the tibialis anterior muscle, around 4 fingerbreadths below the kneecap and 1 fingerbreadth lateral from the anterior crest of the tibia. PC6 is located $2 \mathrm{~cm}$ above the transverse crease of the wrist, between the tendons of muscularis palmaris longus and flexor radialis. symptom scores, gastric emptying, and gastric accommodation. ${ }^{63} \mathrm{~A}$ pilot study investigated the fasting and postprandial effects of TEA at ST36 and PC6 vs sham on gastric motility and accommodation in FD patients and healthy controls. They found that verum TEA significantly increased gastric accommodation in FD patients only, and increased the percentage and power of postprandial gastric slow waves as well as vagal activity in FD patients. ${ }^{64}$ These results suggest that self-administrated TEA can improve gastric motility and symptom relief for $\mathrm{FD}$ patients.

In a study by Köklü et al, ${ }^{65}$ transcutaneous electrical stimulation was conducted via vacuum interferential current therapy. Therapy was superior to placebo in improving epigastric discomfort, pyrosis, bloating, early satiation, and postprandial fullness in FD patients. ${ }^{65}$ The location of electrical stimulation in this study corresponded to 4 acupuncture points: Bladder 18-21. ${ }^{67}$

Vagus nerve stimulation has demonstrated anti-nociceptive effects on various types of pain. ${ }^{68-70} \mathrm{~A}$ recent study showed an impressive analgesic effect using percutaneous electric nerve field stimulation (PENFS) in the external ear to treat patients with functional abdominal pain (including FD patients). ${ }^{66}$ One hundred and 4 adolescents (aged 11-18 years) with chronic functional abdominal pain were enrolled. Fifty-seven received PENFS with 3.2 volts in rectangular pulse wave and alternating frequencies (1 msec pulses of $1 \mathrm{~Hz}$ and $10 \mathrm{~Hz}$ ) every 2 seconds, while the remaining $47 \mathrm{pa}-$ tients received sham stimulation. Patients in the PENFS group had a lower "worst pain score" than with sham group after 3 weeks of treatment ( 5 vs $7, P<0.03$ ). Such analgesic effects were sustained

Table 5. Summary of Non-pharmacological Methods in Management of Functional Dyspepsia

\begin{tabular}{|c|c|c|c|c|}
\hline Category & Methods & Clinical evidence & Efficacy & References \\
\hline Reassurance & Reassurance & Placebo effect in randomized controlled studies & $6-72 \%$ & 21,22 \\
\hline \multirow[t]{3}{*}{ Psychotherapy } & Cognitive behavioral therapy & Randomized controlled studies & $54 \%$ and $87 \%$ & 34,71 \\
\hline & Hypnotherapy & Randomized controlled study & $73 \%$ & 29 \\
\hline & Other psychotherapy & $\begin{array}{l}\text { Meta-analysis of randomized } \\
\text { controlled studies }\end{array}$ & $63-93 \%$ & 37 \\
\hline Food & Gluten free diet & $\begin{array}{l}\text { Retrospective cohort study and } \\
\text { randomized controlled study }\end{array}$ & $86-91 \%$ & $39,72,73$ \\
\hline \multirow[t]{2}{*}{ Medical food } & Caraway oil + peppermint oil & Randomized controlled studies & $61-94 \%$ & $43,44,54,74-76$ \\
\hline & STW 5 & Randomized controlled study & $86 \%$ & 47 \\
\hline Acupuncture & Acupuncture over ST36 and PC6 & $\begin{array}{l}\text { Meta-analysis of randomized } \\
\text { controlled studies }\end{array}$ & $60-97 \%$ & 58,59 \\
\hline \multirow[t]{2}{*}{$\begin{array}{l}\text { Electrical } \\
\text { stimulation }\end{array}$} & $\begin{array}{l}\text { Transcutaneous electrical stimulation } \\
\text { over ST36 and PC6 }\end{array}$ & Single blinded cross-over study & $\begin{array}{l}40 \% \text { improvement } \\
\text { in dyspeptic score }\end{array}$ & 63 \\
\hline & $\begin{array}{l}\text { Percutaneous electric nerve field } \\
\text { stimulation in the external ear }\end{array}$ & Randomized controlled study & $60 \%$ & 66 \\
\hline
\end{tabular}

STW 5, garden angelic root, milk thistle fruits, greater celandine; ST36, Stomach-36; PC6, Pericardium-6. 
for a median follow-up of 9.2 weeks. The authors postulated that such effects might be driven via stimulation of brainstem nuclei involved in pain pathways (ie, nucleus of the solitary tract). Such results suggest that noninvasive PENFS can be a safe and effective therapeutic option for the treatment of pain in patients with functional gastrointestinal disorders. But, again, more studies are necessary to confirm the above findings using different modalities in electrical stimulation/modulation and to determine the most efficient stimulation paradigm, stimulation methods, and treatment duration for the FD patients.

\section{Conclusion}

Non-pharmacological therapies including reassurance, lifestyle modification, psychotherapy, dietary management, medical food, acupuncture, and electrical stimulation/modulation can be useful options for the treatment of FD (Table 5). Non-pharmacological therapies for FD are increasingly being sought by families and medical providers for treating dyspeptic symptoms. The noninvasive nature and potentially minimal side-effects of these nonaddictive, non-pharmacological therapy are likely to benefit FD patients, especially those who have failed conventional therapies. The current evidence to warrant the routine use of non-pharmacological therapies in treating FD patients remains limited, though some FD patients do respond well to non-pharmacological management. The timing to incorporate non-pharmacological therapy into the standard therapy and its position in the current treatment algorithm for FD patients remains to be settled. It is still unclear whether it should be used for refractory FD patients or used as an adjunct to the pharmacological therapy. More well-conducted and large-scaled clinical trials are required to confirm their effectiveness and to identify possible adverse effects in FD treatment.

Financial support: This study was supported by Taipei Veterans General Hospital (Grant No. V107C-153; VTA-107-V1-9-1; VTA-108-V1-3-2).

\section{Conflicts of interest: None.}

Author contributions: Yen-Po Wang: manuscript writing and tables and figure generation; Charles C Herndon: manuscript writing, major revision, and table generation; and Ching-Liang Lu: manuscript writing and critical revision of the manuscript for important intellectual content.

\section{References}

1. Drossman DA. Functional gastrointestinal disorders: history, pathophysiology, clinical features and Rome IV. Gastroenterology 2016;150:12621279, e2.

2. Stanghellini V, Chan FK, Hasler WL, et al. Gastroduodenal disorders. Gastroenterology 2016;150:1380-1392.

3. Ghoshal UC, Singh R, Chang FY, et al. Epidemiology of uninvestigated and functional dyspepsia in Asia: facts and fiction. J Neurogastroenterol Motil 2011;17:235-244

4. Lu CL, Lang HC, Chang FY, et al. Prevalence and health/social impacts of functional dyspepsia in Taiwan: a study based on the Rome criteria questionnaire survey assisted by endoscopic exclusion among a physical check-up population. Scand J Gastroenterol 2005;40:402-411.

5. Gilja OH, Hausken T, Wilhelmsen I, Berstad A. Impaired accommodation of proximal stomach to a meal in functional dyspepsia. Dig Dis Sci 1996;41:689-696.

6. Carbone F, Tack J. Gastroduodenal mechanisms underlying functional gastric disorders. Dig Dis 2014;32:222-229.

7. Mertz H, Fullerton S, Naliboff B, Mayer EA. Symptoms and visceral perception in severe functional and organic dyspepsia. Gut 1998;42:814822.

8. Sugano K, Tack J, Kuipers EJ, et al. Kyoto global consensus report on Helicobacter pylori gastritis. Gut 2015;64:1353-1367.

9. Barbera R, Feinle C, Read NW. Nutrient-specific modulation of gastric mechanosensitivity in patients with functional dyspepsia. Dig Dis Sci 1995;40:1636-1641.

10. Lee KJ, Demarchi B, Demedts I, Sifrim D, Raeymaekers P, Track J. A pilot study on duodenal acid exposure and its relationship to symptoms in functional dyspepsia with prominent nausea. Am J Gastroenterol 2004;99:1765-1773

11. Holtmann G, Siffert W, Haag S, et al. G-protein $\beta 3$ subunit 825 CC genotype is associated with unexplained (functional) dyspepsia. Gastroenterology 2004;126:971-979.

12. Van Oudenhove L, Aziz Q. The role of psychosocial factors and psychiatric disorders in functional dyspepsia. Nat Rev Gastroenterol Hepatol 2013;10:158-167.

13. Futagami S, Itoh T, Sakamoto C. Systematic review with metaanalysis: post-infectious functional dyspepsia. Aliment Pharmacol Ther 2015;41:177-188.

14. Talley NJ, Walker MM, Aro P, et al. Non-ulcer dyspepsia and duodenal eosinophilia: an adult endoscopic population-based case-control study. Clin Gastroenterol Hepatol 2007;5:1175-1183.

15. Talley NJ, Ford AC. Functional dyspepsia. N Engl J Med 2015;373:1853-1863

16. Quigley EMM. Prokinetics in the management of functional gastrointestinal disorders. Curr Gastroenterol Rep 2017;19:53.

17. Freedberg DE, Kim LS, Yang YX. The risks and benefits of long-term use of proton pump inhibitors: expert review and best practice advice from the american gastroenterological association. Gastroenterology 2017;152:706-715. 
18. Lacy BE, Talley NJ, Locke GR 3rd, et al. Review article: current treatment options and management of functional dyspepsia. Aliment Pharmacol Ther 2012;36:3-15.

19. Chiarioni G, Pesce M, Fantin A, Sarnelli G. Complementary and alternative treatment in functional dyspepsia. United European Gastroenterol J 2018;6:5-12.

20. Talley NJ, Locke GR, Lahr BD, et al. Predictors of the placebo response in functional dyspepsia. Aliment Pharmacol Ther 2006;23:923-936.

21. Enck P, Klosterhalfen S. The placebo response in functional bowel disorders: perspectives and putative mechanisms. Neurogastroenterol Motil 2005;17:325-331.

22. Moayyedi P, Soo S, Deeks J, Delaney B, Innes M, Forman D. Pharmacological interventions for non-ulcer dyspepsia. Cochrane Database Syst Rev 2006:CD001960.

23. De la Roca-Chiapas JM, Solís-Ortiz S, Fajardo-Araujo M, Sosa M, Córdova-Fraga T, Rosa-Zarate A. Stress profile, coping style, anxiety, depression, and gastric emptying as predictors of functional dyspepsia: a case-control study. J Psychosom Res 2010;68:73-81.

24. Aro P, Talley NJ, Ronkainen J, et al. Anxiety is associated with uninvestigated and functional dyspepsia (Rome III criteria) in a Swedish population-based study. Gastroenterology 2009;13:94-100.

25. Hsu YC, Liou JM, Liao SC, et al. Psychopathology and personality trait in subgroups of functional dyspepsia based on Rome III criteria. Am J Gastroenterol 2009;104:2534-2542.

26. Miwa $\mathrm{H}$. Life style in persons with functional gastrointestinal disorders-large-scale internet survey of lifestyle in Japan. Neurogastroenterol Motil 2012;24:464-471, e217.

27. Gathaiya N, Locke GR 3rd, Camilleri M, Schleck CD, Zinsmeister AR, Talley NJ. Novel associations with dyspepsia: a community-based study of familial aggregation, sleep dysfunction and somatization. Neurogastroenterol Motil 2009;21:922-e69.

28. Ford AC, Moayyedi P, Lacy BE, et al. American college of gastroenterology monograph on the management of irritable bowel syndrome and chronic idiopathic constipation. Am J Gastroenterol 2014;109(suppl 1):S2-S26.

29. Calvert EL, Houghton LA, Cooper P, Morris J, Whorwell PJ. Longterm improvement in functional dyspepsia using hypnotherapy. Gastroenterology 2002;123:1778-1785.

30. Dehghanizade Z, Zargar Y, Mehrabizadeh Honarmand M, Kadkhodaie A, Eydi Baygi M. The effectiveness of cognitive behavior stress management on functional dyspepsia symptoms. J Adv Med Educ Prof 2015;3:45-49.

31. Cheng C, Yang FC, Jun S, Hutton JM. Flexible coping psychotherapy for functional dyspeptic patients: a randomized, controlled trial. Psychosom Med 2007;69:81-88.

32. Orive M, Barrio I, Orive VM, et al. A randomized controlled trial of a 10 week group psychotherapeutic treatment added to standard medical treatment in patients with functional dyspepsia. J Psychosom Res 2015;78:563-568.

33. Haug TT, Wilhelmsen I, Svebak S, Berstad A, Ursin H. Psychotherapy in functional dyspepsia. J Psychosom Res 1994;38:735-744.

34. Haag S, Senf W, Tagay S, et al. Is there a benefit from intensified medi- cal and psychological interventions in patients with functional dyspepsia not responding to conventional therapy? Aliment Pharmacol Ther 2007;25:973-986.

35. Faramarzi M, Azadfallah P, Book HE, Tabatabaei KR, Taheri H, Shokri-shirvani J. A randomized controlled trial of brief psychoanalytic psychotherapy in patients with functional dyspepsia. Asian J Psychiatr 2013;6:228-234.

36. Hamilton J, Guthrie E, Creed F, et al. A randomized controlled trial of psychotherapy in patients with chronic functional dyspepsia. Gastroenterology 2000;119:661-669.

37. Moayyedi P, Lacy BE, Andrews CN, Enns RA, Howden CW, Vakil N. ACG and CAG clinical guideline: management of dyspepsia. Am J Gastroenterol 2017;112:988-1013.

38. Tack J, Talley NJ, Camilleri M, et al. Functional gastroduodenal disorders. Gastroenterology 2006;130:1466-1479.

39. Duncanson KR, Talley NJ, Walker MM, Burrows TL. Food and functional dyspepsia: a systematic review. J Hum Nutr Diet 2018;31:390407.

40. Göktaş Z, Köklü S, Dikmen D, et al. Nutritional habits in functional dyspepsia and its subgroups: a comparative study. Scand J Gastroenterol 2016;51:903-907.

41. Acker BW, Cash BD. Medicinal foods for functional GI disorders. Curr Gastroenterol Rep 2017;19:62.

42. Ciampa BP, Reyes Ramos E, Borum M, Doman DB. The emerging therapeutic role of medical foods for gastrointestinal disorders. Gastroenterol Hepatol 2017;13:104-115.

43. Madisch A, Heydenreich CJ, Wieland V, Hufnagel R, Hotz J. Treatment of functional dyspepsia with a fixed peppermint oil and caraway oil combination preparation as compared to cisapride. A multicenter, reference-controlled double-blind equivalence study. Arzneimittelforschung 1999;49:925-932.

44. May B, Köhler S, Schneider B. Efficacy and tolerability of a fixed combination of peppermint oil and caraway oil in patients suffering from functional dyspepsia. Aliment Pharmacol Ther 2000;14:1671-1677.

45. Malfertheiner P. STW 5 (Iberogast) therapy in gastrointestinal functional disorders. Dig Dis 2017;35(suppl 1):25-29.

46. Melzer J, Rösch W, Reichling J, Brignoli R, Saller R. Meta-analysis: phytotherapy of functional dyspepsia with the herbal drug preparation STW 5 (Iberogast). Aliment Pharmacol Ther 2004;20:1279-1287.

47. von Arnim U, Peitz U, Vinson B, Gundermann KJ, Malfertheiner P. STW 5, a phytopharmacon for patients with functional dyspepsia: results of a multicenter, placebo-controlled double-blind study. Am J Gastroenterol 2007;102:1268-1275.

48. Braden B, Caspary W, Börner N, Vinson B, Schneider AR. Clinical effects of STW 5 (Iberogast) are not based on acceleration of gastric emptying in patients with functional dyspepsia and gastroparesis. Neurogastroenterol Motil 2009;21:632-638, e25.

49. Leelakusolvong S, Limsrivilai J, Charatcharoenwitthaya P, Pausawasdi N. Response to marsden and ford. Am J Gastroenterol 2016;111:13581359.

50. Sáez-González E, Conde I, Díaz-Jaime FC, Benlloch S, Prieto M, Berenguer M. Iberogast-induced severe hepatotoxicity leading to liver 
transplantation. Am J Gastroenterol 2016;111:1364-1365.

51. Degnan FH. The US food and drug administration and probiotics: regulatory categorization. Clin Inf Dis 2008;46(suppl 2):S133-S136; discussion S144-S151.

52. Ohtsu T, Takagi A, Uemura N, et al. The ameliorating effect of Lactobacillus gasseri OLL2716 on functional dyspepsia in Helicobacter pylori-uninfected individuals: a randomized controlled study. Digestion 2017;96:92-102.

53. Nakae H, Tsuda A, Matsuoka T, Mine T, Koga Y. Gastric microbiota in the functional dyspepsia patients treated with probiotic yogurt. BMJ Open Gastroenterol 2016;3:e00109.

54. Chey WD, Lacy BE, Cash BD, Epstein M, Shah SM. Efficacy of caraway oil//-menthol plus usual care vs placebo plus usual care, in functional dyspepsia patients with post-prandial distress (PDS) or epigastric pain (EPS) syndromes: results from a US RCT. Gastroenterology 2017;152:S307.

55. Rösch W, Vinson B, Sassin I. A randomised clinical trial comparing the efficacy of a herbal preparation STW 5 with the prokinetic drug cisapride in patients with dysmotility type of functional dyspepsia. Z Gastroenterol 2002;40:401-408.

56. Xiao M, Qiu X, Yue D, Cai Y, Mo Q. Influence of hippophae rhamnoides on two appetite factors, gastric emptying and metabolic parameters, in children with functional dyspepsia. Hell J Nucl Med 2013;16:38-43.

57. Langevin HM, Schnyer R, MacPherson H, et al. Manual and electrical needle stimulation in acupuncture research: pitfalls and challenges of heterogeneity. J Alterm Complement Med 2015;21:113-128.

58. Kim KN, Chung SY, Cho SH. Efficacy of acupuncture treatment for functional dyspepsia: a systematic review and meta-analysis. Complement Ther Med 2015;23:759-766.

59. Zhou W, Su J, Zhang H. Efficacy and safety of acupuncture for the treatment of functional dyspepsia: meta-analysis. J Altern Complement Med 2016;22:380-389.

60. Zeng F, Qin W, Ma T, et al. Influence of acupuncture treatment on cerebral activity in functional dyspepsia patients and its relationship with efficacy. Am J Gastroenterol 2012;107:1236-1247.

61. Lan L, Zeng F, Liu GJ, et al. Acupuncture for functional dyspepsia. Cochrane Database Syst Rev 2014:CD008487.

62. Chen JDZ, Ni M, Yin J, et al. Electroacupuncture treatments for gut motility disorders. Neurogastroenterol Motil 2018;30:e13393.

63. Ji T, Li X, Lin L, et al. An alternative to current therapies of functional dyspepsia: self-administrated transcutaneous electroacupuncture improves dyspeptic symptoms. Evid Based Complement Alternat Med 2014;2014:832523

64. Xu F, Tan Y, Huang Z, Zhang N, Xu Y, Yin J. Ameliorating effect of transcutaneous electroacupuncture on impaired gastric accommodation in patients with postprandial distress syndrome-predominant functional dyspepsia: a pilot study. Evid Based Complement Alternat Med 2015;2015:168252.

65. Köklü S, Köklü G, Ozgüçlü E, Kayani GU, Akbal E, Hasçelik S. Clinical trial: interferential electric stimulation in functional dyspepsia patients a prospective randomized study. Aliment Pharmacol Ther 2010;31:961968.

66. Kovacic K, Hainsworth K, Sood M, et al. Neurostimulation for abdominal pain-related functional gastrointestinal disorders in adolescents: a randomised, double-blind, sham-controlled trial. Lancet Gastroenterol Hepatol 2017;2:727-737.

67. Beyazit Y, Kekilli M, Purnak T. Effects of transcutaneous electrical acustimulation in patients with functional dyspepsia. Aliment Pharmacol Ther 2010;31:1371-1372; author reply 1373.

68. Busch V, Zeman F, Heckel A, Menne F, Ellrich J, Eichhammer P. The effect of transcutaneous vagus nerve stimulation on pain perception-an experimental study. Brain Stimul 2013;6:202-209.

69. Oshinsky ML, Murphy AL, Hekierski H Jr, Cooper M, Simon BJ. Noninvasive vagus nerve stimulation as treatment for trigeminal allodynia. Pain 2014;155:1037-1042.

70. Gaul C, Diener HC, Silver N, et al. Non-invasive vagus nerve stimulation for PREVention and acute treatment of chronic cluster headache (PREVA): a randomised controlled study. Cephalalgia 2016;36:534-546.

71. Cao J, Ren X, Zhu G. Sa1116 significance of double steps reattribution integrative model for patients with functional dyspepsia (FD). Gastroenterology 2013;144:S205-S206.

72. Elli L, Tomba C, Branchi F, et al. Evidence for the presence of non-celiac gluten sensitivity in patients with functional gastrointestinal symptoms: results from a multicenter randomized double-blind placebo-controlled gluten challenge. Nutrients 2016;8:84.

73. Santolaria Piedrafita S, Fernández Bañares F. [Gluten-sensitive enteropathy and functional dyspepsia.] Gastroenterol Hepatol 2012;35:78-88. [Spanish]

74. May B, Kuntz HD, Kieser M, Köhler S. Efficacy of a fixed peppermint oil/caraway oil combination in non-ulcer dyspepsia. Arzneimittelforschung 1996;46:1149-1153.

75. Freise J, Köhler S. [Peppermint oil-caraway oil fixed combination in non-ulcer dyspepsia--comparison of the effects of enteric preparations.] Pharmazie 1999;54:210-215. [German]

76. Shams R, Oldfield EC, Copare J, Johnson DA. Peppermint oil: clinical uses in the treatment of gastrointestinal diseases. JSM Gastroenterol Hepatol 2015;3:1035-1046. 